\title{
Mouse Trisomy 16
}

National Cancer Institute

\section{Source}

National Cancer Institute. Mouse Trisomy 16. NCI Thesaurus. Code C125660.

A mouse chromosomal abnormality consisting of the presence of a third copy of

chromosome 16 in somatic cells. Mice that are trisomic for chromosome 16 offer a genetic model for studies relevant to Down syndrome. 